\title{
Conceptual Framework for Enhancing the Implementation of Specific Microfinance Policies in Sub-Sahara Africa
}

Kwami Hope Quao, Abersytwyth University Mauritius, Uniciti, Mauritius

\begin{abstract}
Deficient policy formulation processes and inadequate monitoring and supervision remain factors impeding the growth of microfinance in sub-Saharan Africa. This article explores issues mitigating policy implementation for microfinance institutions to propose a framework that will integrate stakeholders in the microfinance sector for effective financial policy implementation and promotion of microfinance performance and growth. The article proposes financial monitoring policy ownership structure and argues for the creation of an independent national microfinance supervisory authority as an alternative to ensuring effective implementation of microfinance policies in Ghana. This framework, the authors argue, will enhance stakeholder engagement in police formulation and create the necessary implementation environment, with adequate information, in which policy implementation for microfinance will flourish.
\end{abstract}

\section{KEYWORDS}

Formulation, Implementation, Microfinance, Monitoring, Policy, Strategy

\section{INTRODUCTION}

Microfinance institutions (MFIs) are financial institutions with social agenda of deepening financial inclusion to alleviate poverty via the provision of finance to the hardcore poor who do not have access to the conventional banks (Addae-Korankye, 2012). The success of the strategy was well pronounced until there was a shift from the primary social focus to commercialization and acceptance of deposits from their clients. This later practice prompted the call for regulation for the financial subsector (Smith \& Katikireddi).

Research on regulating microfinance institutions (MFIs) (Smith \& Katikireddi, 2012; May, 2014: 1-23) to promote financial sanity and arrest the numerous problems (Addae-Korankye, 2012; Ojo, 2013; Boateng, 2015) besetting the sector yielded significant results but equal attention was not given to implementation of such regulations and policies to realize the objective of regulating (May, 2014: 1-23; Little, 2012) the financial subsector. Much therefore has not changed since the institution of various types of regulation for microfinance (MF) in sub-Sahara Africa (SSA) countries, particularly in Ghana. Despite crafting sector regulations (BoG, 2011; 2013) the recent financial scandal of DKM which robbed hundreds of depositors of their hard-earned income (Sarpong, 2016) proves that the mere presence of policies is not enough. Many observants blamed the phenomenon on the less effective supervision and monitoring by the Bank of Ghana thereby giving the MFIs a leeway to exploit their clients. This prompts this study to ask why the sub-optimal performance and rampant collapse and closure of the MFIs in Ghana. 
The aim of the article is to explore the formulation process, the level of stakeholder engagement and compliance and commitment to implementation in order to propose a structure that may promote effective integrated policy formulation, review and implementation to enhance sustainability, growth and performance of the MFIs sector. This is done by providing answers to 'How was the current microfinance specific guidelines formulated?', 'What was the level of stakeholder participation in the formulation and review of the current policy?' and 'How is implementation and compliance employed?'

The rest of this article looks at brief literature, methodology, discussion of findings, the proposed model framework for stakeholder engagement for effective policy implementation and conclusion.

\section{LITERATURE REVIEW}

Empirical review presented considered MF regulation and implementation strategies in SSA and is interspersed with policy formulation theory and process, implementation theory and environments as well as a number of relevant policy implementation models.

\section{Policy Formulation Theory and Process for MFIs}

Many authors define policy formulation at two broad levels: problem identification and definition which Embrett \& Randall (2014) refer to as the agenda setting stage and actual formulation; including decision-making and implementation and evaluation stages. Santos (2012, p. 339) however indicates environment specificity approach to policy making. Similarly, Embrett \& Randall (2014) aver policy formulation for microfinance should be random and erratic yet country specific (CGAP, 2011) as MF activities are complex; dictated by the environment that creates them (Santos (2012).

The complex activities of MF correlate with Little (2012, p. 16) and Geyer's (2012) call for the complexity theory of policy formulation (Hallsworth \& Rutter, 2011, p. 18; Cairney, 2012, pp. 1-14) which intimates that policy formulation should be regarded as a system. Therefore, policymaking involves many ideas interacting in a non-linear fashion (Smith \& Katikireddi, 2012; Embrett \& Randall, 2014); drawing cooperation from policymakers and implementers to ensure that those interactions (Geyer, 2012) can produce new ideas and ways of thinking (Pritchett et al., 2012).

\section{Microfinance Policy Implementation}

Most MFIs in SSA are regulated and supervised by the individual country's central bank: Nigeria (CBN), Egypt (CBE), Kenya (CBK), Uganda (BoU), Ghana (BoG) and Zimbabwe (RBZ), are but a few examples (Khalily, Khaleque \& Badruddoza, 2014, pp. 1-32). The central bank licenses the MFIs in these countries (Mago, 2013). In South Africa, however, the Microfinance Regulatory Council (MFRC) carries out the supervisory activities by conducting random off-site and on-site inspections on the MFIs (Segun, Hussein, Daniel \& Olajide, 2015) as defined by the Usury Act. While many MFIs remain illegal and thus obviously have no regulation or self-regulation (SRO) via apex institutions like Ghana Microfinance Network (GHAMFIN) and allied institutions such as Ghana Association of Microfinance Companies (GAMC) and Microfinance and Small Loans Centre (MANSLOC) of Ghana, regulations with a non-prudential element and a hybrid of non-prudential and prudential regulations can be found (Macchiavello, 2012) in SSA countries.

Given the peculiar nature of MF activities (CGAP, 2011), a special law regulation for MFIs is considered in Bangladesh, Kenya, Nigeria and South Africa but Segun et al. (2015, p. 81) argue that maintaining self-regulation, with the existing banking laws (Khalily et al., 2014, pp. 1-32) of the respective countries, proves more efficient than crafting entirely special MF-specific laws. However, Zimbabwe, Mozambique and Uganda, like the Philippines, have successfully enacted a special law for their MFIs (Makuyana, 2016) to ensure there is specific regulation tailored to the relative environment (CGAP, 2011; Santos, 2012, p. 339) of the MFIs in these countries. 
Unlike India, Peru, Bolivia, the Philippines and many other countries, supervision and monitoring of MFIs in SSA remains largely the jurisdiction of the central banks of the individual countries. This is widely criticized because the central banks are inundated with numerous tasks (Wampah, 2012; Nzaro et al., 2013) including the broad economic and the financial system management in their mandate. The implication is that the respective departments exert less control over the MFIs, hence implementation of the relevant financial policies and supervision and monitoring suffer (Addae-Korankye, 2014; Ojo, 2013). Nzaro et al. (2013) and Makuyana (2016) therefore posit an independent body to carry out the duty of supervision and monitoring of MFIs in developing economies, as is the case in Bangladesh. This view corresponds to the implementation concept this paper is purposed to define for Ghana.

In Ghana, effective regulation for MFIs was initiated in 2011, resulting in the creation of tier categorization of the MF sector for registration and operational purposes (BoG, 2011, 2012). However, the adoption of self-regulation and role overlap of the various apex bodies in the sector, and less involvement of the BoG in broad base supervision, rather dispel the benefits of any regulation to promoting efficient course for the MF sector growth and sanity.

\section{Policy Implementation Modes for MF}

Regulators apply risk management approach (Ojo, 2013, pp. 1-13) to supervise all the financial institutions, including conventional banks, which capital and operational models differ from MFIs. For MF peculiar nature, the need for regulators to adjust their policies so that the MFIs fit into these risk management practices (Magali, 2014; Wilkinson \& Frost, 2015; May, 2013, pp. 1-14; Geyer, 2012) has become more imperative. Ali (2015a, p. 125) posits that MFIs must be able to enter the arena of a licensed and prudentially supervised financial intermediation, while at the same time, regulations must be crafted in such a way that permits effective and efficient development (Turner, 2012; Rahman \& Luo, 2012) of MFIs. Entry requirements based on minimum capital requirements, ownership criteria and capital to asset ratio are more prudential specifications (Khalily et al., 2014, p. 25); and are preventive measures for sufficiently efficient MF operations. This is why rigorous preventive regulation might not be appropriate in the Ghanaian MF sector and hence, Ghana's MF sector is less-regulated and subject to different jurisdiction (BoG, 2013). Despite its laudable crafty regulation the BoG is using base capital requirement to determine and prescribe the legal standing and continuous operation of the MFIs; evidenced by near annual increases in minimum capital requirements (2015). A clear-cut policy on the MF operations in Ghana is therefore highly imperative, emphasized by Amponsah, Chairman of MFIs. This is further emphasized by Deputy-Governor of BoG, Mrs. Elsie Addo Awadzi, when she stressed on the inability of the MFIs to pay interest and most often the principal deposit of their clients due to poor performance at the JoyBusiness Financial Services Forum and hence the BoG's resolve to close down 200 or more MFIs in the near future.

\section{MF Policy Implementation Environments}

Since MFIs are social enterprises and the environment determines their nature and legal form (Santos, 2012, p. 335), a dynamic environment of this nature (Cairney, 2012, p. 8) means policies for MFIs must be aligned (Rycroft-Malone et al., 2013, p. 29) to their specific operating determinants.

Inferring from the various models, policy implementation therefore, needs to have a holistic view of the MFIs' environment and consider the networks of these institutions and inter-organizational relationships (Cairney, 2012, pp. 37-38; Little, 2012, p. 16; May, 2013, pp. 26-33). May indicates that the implementation process expresses in agency; the MFIs. The author further explains that the implementation processes are interactions between 'emergent expressions of agency' (2013, pp. 1-14). Thus, what MFIs do to make something happen and the ways they work with different components of a complex intervention as well as 'dynamic elements of context' (Cairney, 2012, p. 8), which explain the social-structural and social-cognitive resources they draw on to realize that agency, explains how MFIs implement their requisite operating guidelines. 
The implementation of every policy is a dynamic process, which involves the interaction of many variables (Hoekstra, Alingh, van der Schans, Hettinga, Duijf, M., Dekker \& van der Woude, 2014, p. 8; Hallsworth \& Rutter, 2011, p. 18; Geyer, 2012, pp. 3-19). The paper identifies that the implementation process of regulations for MFIs is characterized by certain key factors peculiar to the MF industry, referred to as 'determinants or environments' in this context. These determinants interact to promote or hinder MF policy implementation in the financial sector. The implementation determinants (Hoekstra et al., 2014, p. 8), in this regard, include some key characteristics of the MFIs, bureaucratic structure, communication resources and others as summarized in Table 1.

\section{Developing Effective Implementation Concept}

May (2013, pp. 1-14) proposes integrative models, such as Berman's Ambiguity-Conflict model (Nilsen et al., 2013; Nilsen, 2015), the Vertical model (Gong and Janssen, 2012), Elmore's ForwardBackward mapping model, and the Interactive model, to policy implementation shortcomings. This study subscribes to this proposition, in order to develop an integrated policy ownership framework relevant to the MF environment.

Organizational and agency theories indicate how ambiguity (May, 2013, pp. 1-14; May, 2014, pp. 1-13; Cairney, 2012; Hallsworth \& Rutter, 2011, p. 18) and conflict (Nilsen et al., 2013) affect decision-making and implementation. Placing a policy in an agency where it conflicts with existing policies and goals will therefore, lead to few resources, little support, and almost certain failure (Gong $\&$ Janssen, 2012). Though the guidelines for MF are not conflicting, the bottom-line is that MFIs find it difficult meeting the existing requirements, hence the quest to formulate more stringent regulations (BoG, 2015), as their operation could not produce any valid impact (Boateng, 2015).

Cairney (2012, p. 38) expresses the same view to indicate the complexity of the implementation object; the policy. Cairney's assertion points to the contribution to policymaking by all actors in the implementation process, drawing on existing resources and in consideration of the target's particular setting, to explain how implementation processes are largely collective and collaborative (May, 2013, pp. 1-14) in their form and direction.

May (2013, pp. 1-14) further explains that Barrett and Fudge's 1981 Action-Centred and Policy-Action models identified the agency as what must be achieved, the agent as the implementer (MFIs), and the structure as the rules and resources for implementation, within which the process of implementation occurs. The Action-Centred model which emphasizes negotiation and performance fits advocates of the bottom-up approach to policy formulation, which is participatory and allinclusive, whilst the Policy-Action model seeks to attribute the implementation process to availability of structures, comprising rules and resources, and deepens the understanding of the entire process. Integrating these models will explain the diversity, complexity and interaction necessary to exact successful MF policy implementation.

\section{RESEARCH METHODOLOGY}

This paper explores the mixed approach using qualitative secondary data and quantitative primary data. A questionnaire was used to collect adequate relevant primary data. The questionnaire aimed at determining whether the Tier 2 MFIs in Ghana: participate in formulating policies impacting their operations; are adequately complying with the banking operation guidelines and to identify the policy implementation challenges facing the MFIs in order to propose a conceptual framework that will improve policy adoption and compliance among the MFIs. This was complemented by literature on various policy formulation and implementation theories.

The questionnaire requested respondents to indicate on a 5-point Likert scale their views and experiences regarding specific questions about the MF operating guidelines in Ghana. It also measured MFIs level of input in policy formulation and review and specific implementation challenges.

The study was conducted among 63 Tier 2 level MFIs in Accra. The respondents comprising operations and other senior level managers who represented the key role players involved in major 
Table 1. Description of MF policy implementation determinants

\begin{tabular}{|c|c|c|}
\hline \multicolumn{2}{|c|}{$\begin{array}{l}\text { Determinants/ } \\
\text { Environments }\end{array}$} & Relevant Description Pertaining to the MFI Sector \\
\hline 1 & $\begin{array}{l}\text { Sector } \\
\text { characteristics }\end{array}$ & $\begin{array}{l}\text { Sector characteristics define MFIs as social enterprise and their operation mechanism } \\
\text { (Santos, 2012, pp. 337-338). These define the legal form (Rivera-Santos et al., 2012; } \\
\text { Montgomery et al., 2012, pp. 375-388) of the MFIs and their operations. The CGAP } \\
\text { proposes MF regulations to be tailored to country specific situations, even though MF } \\
\text { activities across the globe exhibit similar sector characteristics (CGAP, 2011, 2012). The } \\
\text { Ghanaian economic situation and the culture of the people therefore, spell how the MFIs } \\
\text { respond and adapt to the relevant regulations (BoG, 2013). }\end{array}$ \\
\hline 2 & $\begin{array}{l}\text { Regulatory } \\
\text { outcomes }\end{array}$ & $\begin{array}{l}\text { This characteristic explains the target of the regulator, what MFIs must do to achieve such } \\
\text { set goals and requirements embedded in the available and reviewed regulations pertaining } \\
\text { to MFIs, to remain sound and achieve sanity in their operations. The policy guidelines } \\
\text { regarding the tier system, as practiced in Ghana, Tanzania, Uganda, and other countries } \\
\text { in Asia, makes it difficult for MFIs to delineate their activities (Magali, 2014). Cross-tier } \\
\text { operations and illegal operators are thus given leeway, due to the high level of ambiguity } \\
\text { that characterizes the policy frameworks. The policy outcome determines the dos and } \\
\text { don'ts and the prescribed path of the implementation process (Rivera-Santos et al., 2012; } \\
\text { Montgomery et al., 2012) the MFIs must follow. }\end{array}$ \\
\hline 3 & $\begin{array}{l}\text { Firm structure } \\
\text { and resources }\end{array}$ & $\begin{array}{l}\text { This characteristic explains the capability of MFIs to internalize these regulations } \\
\text { in their operating strategies. It calls for physical and non-physical resources, such as } \\
\text { communication infrastructure (Mago, 2013; Little, 2012, p. 13) and sound management } \\
\text { skills (Dahir, 2015; Addae-Korankye, 2012, p. 136). Writers decry the inadequacy of } \\
\text { infrastructure to aid MFIs in their operations (Wampah, 2012; Boateng, 2015, p. 11; } \\
\text { Mago, 2013, p. 165). African MFIs (Riquet \& Poursat, 2013: 1) as much as several others } \\
\text { in Asia and Latin America are noted; a phenomenon largely ascribed to the relative small } \\
\text { size of many of these MFIs. }\end{array}$ \\
\hline 4 & $\begin{array}{l}\text { Operational } \\
\text { methodology }\end{array}$ & $\begin{array}{l}\text { Linked with the regulations that determine the extent of operation of the MFIs, } \\
\text { methodologies indirectly tell the regulator the compliance level achieved by the MFIs, as } \\
\text { per the available requirements the institutions must meet (BoG, 2013). Any digression } \\
\text { from the dictates of the regulation means MFIs are operating outside the regulatory } \\
\text { requirements (Ogbolu et al., 2015). Ghana closed } 31 \text { MFIs in } 2013 \text { and numerous others } \\
\text { that did not meet the current regulatory requirement had their licenses withdrawn. The } \\
\text { MRA of India, the sole licensing and supervising authority for MFIs in India, does the } \\
\text { same by withdrawing licenses to enforce the regulations (Rahman \& Luo, 2012). }\end{array}$ \\
\hline 5 & $\begin{array}{l}\text { Management } \\
\text { quality }\end{array}$ & $\begin{array}{l}\text { Put to use! It takes awareness, skills and a certain amount of managerial competence } \\
\text { to apply the relevant regulations (Ojo, 2013, p. 6). It takes astute and experienced } \\
\text { management to understand and embed regulatory requirements into daily operation of } \\
\text { MFIs. This is achieved by continuous training or learning and growth to brace up all } \\
\text { staff to achieve institutional standards. Addae-Korankye (2012, p. 139) and Ali (2015a) } \\
\text { identify poor quality management as a crippling factor affecting MFIs governance in } \\
\text { Ghana and Kenya and Tanzania. }\end{array}$ \\
\hline 6 & Clientele & $\begin{array}{l}\text { Across the globe customers of MFIs are the poor, who lack access to formal financial } \\
\text { institutions (Nzaro et al. 2013; Ali, 2015a, 2015b). The diverse needs of the poor, given } \\
\text { country specifics (CGAP, 2011), dictate the approach each MFI offers its clients. In Accra } \\
\text { (Ghana), the larger clientele of MFIs comprised mostly smallholder market women and } \\
\text { artisans (Mensah, 2013). Variability of client demands, in terms of loan arrangements, is } \\
\text { directly linked with MFIs method of operation and regulation implementation, as well as } \\
\text { compliance. The social enterprise characteristics (Santos, 2012, p. 337) of MFIs therefore, } \\
\text { prove that client demand could be a source of compliance or non-compliance (Kinde, } \\
\text { 2012, p. 2) to operation guidelines regarding MFIs. }\end{array}$ \\
\hline
\end{tabular}

Source: Adapted for this paper (Quao, 2017)

decision making were purposefully chosen because it is usually at this level where processes and regulations are really implemented and where the success of such implementations can be determined. The data gathered was organized into frequencies and correlations for descriptive analysis. 


\section{DISCUSSION AND FINDINGS}

May (2013: 1-14) and other bottom-up theorists, criticize the centralized top-down policy-making strategy and vouched that policy formulation should include the implementers (Michael Lipsky's street-level bureaucrat proposition) at the bottom of the pyramid. For the purpose of assessing the formulation of FMPs for MFIs in Ghana, this study analyzed stakeholder engagement in crafting such policies; the results indicate low participation.

The data gathered from the MFIs regarding their involvement (Table 2) in the policy formulation process as well as availability of supplementary information or guidelines (Table 2) to facilitate the application of the various regulations for the MFIs indicated frustrating results. More than half of the respondents (51.6 percent) indicated that policy formulation for MFIs promotion was devoid of the institutions' participation, while 26.7 percent, indicated some participation. Similarly, 62.3 percent of the respondents disagree on any supplementary materials made available to enhance understanding of the regulation requirements and hence, their proper implementation. In both cases, it is confirmed that guidelines for MF (BoG, 2011) promotion does exist but stakeholders are not full involved in making it. This result indicates that implementation bottlenecks (Song et al., 2015; Kinde, 2012, p. 2; Little, 2012) associated with top-down policies are probable hitches for implementing FMP by MFIs in Ghana. Hoekstra et al. (2014, p. 8) posit that policy implementation is successful when such policies are adopted and implementation environments are created. The 73.3 percent disagreement indicates the authoritative nature and little or no communication for adoption of the policies for MFIs in Ghana. The survey results also prove sufficiently that many of the MFIs do not receive any further notification and or guidance to facilitate implementation of the relevant regulations.

Also, effective policy implementation involves communication and dosage administered, as well as the disposition of the MFIs are pertinent factors to ensure success. The findings on whether there is good dialogue and cooperation are presented in Table 2 above. The data indicated that majority of respondents, (65.0 percent) agreed that the level of dialogue and cooperation that ensue between the MFIs and the policymakers is not resonance enough to promote adequate understanding and implementation of the required regulations in the daily operations of the MFIs. However, $31.7 \%$ disagree; these have a good chunk of the sector market.

While assessing the level of support given to the MFIs in Ghana, the objective of establishing the GAMC which was to enhance capacity building for all registered MFIs in the sector and to promote an enabling environment for sector sustenance was recalled. Song et al. (2015) and Puyvelde, Caers, Du Bois \& Jegers (2012) indicate the need for some institutional structures to promote policy implementation just as Hoekstra et al. (2014, p. 8) indicated an implementation environment is imperative for effective implementation of policy for MFIs; a system of authoritative norms, rules and practices that will be cardinal to realizing a sound system of implementation. On the contrary, this study found that (see Table two) such supports structures are grossly lacking in Ghana.

The results as to whether MFIs in Accra receive funding support from government or any governmental institutions, along with the results of support regarding governance of the MFIs both received disagreement with 53.2 percent and 58.1 percent, respectively.

Other factors assessed include the presence of effective supervision. Monitoring and supervision reveal whether policies are well implemented, the problems encountered and the need for review of the policies. The question as to the effectiveness of supervision of the MFIs by the GAMC, MoFEP and BoG in Accra depict that monitoring and supervision are less effective. The figures (see Table 2) show the results of responses obtained from the survey on supervision by MF regulating institutions. On the part of the MF parent association, the GAMC, the analyzed results indicate an alarming 79.7 percent of ineffectiveness of GAMC in instituting close supervision, whilst 20.3 percent affirmed some supervision from the parent association. Similar results were obtained for MoFEP, which has roles to play in maintaining operational discipline in the MF sector. A 66.7 percent of the valid responses indicated the poor role of the MoFEP in supervising the MFIs, whilst 14.3 percent remained neutral. 
Table 2. Summary of pattern for implementation challenges

\begin{tabular}{|c|c|c|c|c|c|c|c|}
\hline & \multicolumn{2}{|c|}{ Disagree } & \multicolumn{2}{|c|}{ Neutral } & \multicolumn{2}{|c|}{ Agree } & \multirow{2}{*}{$\begin{array}{c}\text { Chi } \\
\text { Square } \\
\text { p-Value }\end{array}$} \\
\hline & Count & $\begin{array}{l}\text { Row } \\
\text { N \% }\end{array}$ & Count & $\begin{array}{l}\text { Row } \\
\text { N \% }\end{array}$ & Count & $\begin{array}{l}\text { Row } \\
\text { N \% }\end{array}$ & \\
\hline Minimum capital requirement & 14 & $22.6 \%$ & 2 & $3.2 \%$ & 46 & $74.2 \%$ & 0.000 \\
\hline Reporting requirements & 11 & $18.0 \%$ & 4 & $6.6 \%$ & 46 & $75.4 \%$ & 0.000 \\
\hline Capital adequacy & 14 & $23.0 \%$ & 3 & $4.9 \%$ & 44 & $72.1 \%$ & 0.000 \\
\hline MoFEP & 10 & $16.7 \%$ & 9 & $15.0 \%$ & 41 & $68.3 \%$ & 0.000 \\
\hline BoG & 14 & $23.0 \%$ & 2 & $3.3 \%$ & 45 & $73.8 \%$ & 0.000 \\
\hline SEC & 10 & $16.1 \%$ & 28 & $45.2 \%$ & 24 & $38.7 \%$ & 0.013 \\
\hline Apex associations & 10 & $18.2 \%$ & 3 & $5.5 \%$ & 42 & $76.4 \%$ & 0.000 \\
\hline $\begin{array}{l}\text { The regulations are constantly } \\
\text { reviewed to meet the current market } \\
\text { needs of the MFIs }\end{array}$ & 8 & $13.3 \%$ & 14 & $23.3 \%$ & 38 & $63.3 \%$ & 0.000 \\
\hline $\begin{array}{l}\text { There is sufficient stakeholder } \\
\text { participation in policy-making } \\
\text { procedures. }\end{array}$ & 31 & $51.7 \%$ & 13 & $21.7 \%$ & 16 & $26.6 \%$ & 0.010 \\
\hline $\begin{array}{l}\text { There is no co-operation and close } \\
\text { dialogue between the police-making } \\
\text { bodies and the individual institutions }\end{array}$ & 19 & $31.7 \%$ & 2 & $3.3 \%$ & 39 & $65.0 \%$ & 0.000 \\
\hline $\begin{array}{l}\text { Compliance to operational guidelines } \\
\text { is inadequate }\end{array}$ & 16 & $25.8 \%$ & 9 & $14.5 \%$ & 37 & $59.7 \%$ & 0.000 \\
\hline Supervision and compliance & 31 & $52.5 \%$ & 16 & $27.1 \%$ & 12 & $20.3 \%$ & 0.006 \\
\hline $\begin{array}{l}\text { Offsite monitoring (submission } \\
\text { of reports) and on-site monitoring } \\
\text { (institution visits and assessments) are } \\
\text { really not integrated }\end{array}$ & 9 & $14.3 \%$ & 11 & $17.5 \%$ & 43 & $68.3 \%$ & 0.000 \\
\hline $\begin{array}{l}\text { Feedback on financial monitoring } \\
\text { reports and references for future } \\
\text { actions are rarely provided }\end{array}$ & 14 & $22.6 \%$ & 5 & $8.1 \%$ & 43 & $69.4 \%$ & 0.000 \\
\hline $\begin{array}{l}\text { Reporting requirements and frequency } \\
\text { of reporting are rather rigid and do } \\
\text { not create suitable environment for } \\
\text { sustainability of the MFIs }\end{array}$ & 12 & $19.0 \%$ & 8 & $12.7 \%$ & 43 & $68.3 \%$ & 0.000 \\
\hline $\begin{array}{l}\text { There is adequate supplementary } \\
\text { guideline or information on the } \\
\text { relevant regulations }\end{array}$ & 38 & $62.3 \%$ & 5 & $8.2 \%$ & 18 & $29.5 \%$ & 0.000 \\
\hline $\begin{array}{l}\text { The level of competition from the } \\
\text { conventional banks is high }\end{array}$ & 4 & $6.3 \%$ & 1 & $1.6 \%$ & 58 & $92.1 \%$ & 0.000 \\
\hline $\begin{array}{l}\text { Human resource and capacity building } \\
\text { for MFIs is lacking }\end{array}$ & 13 & $20.6 \%$ & 3 & $4.8 \%$ & 47 & $74.6 \%$ & 0.000 \\
\hline $\begin{array}{l}\text { The constant amendment of the } \\
\text { banking operating guidelines for MF, } \\
\text { and sections therein, is devastating } \\
\text { service provision and highly } \\
\text { operationally restrictive. }\end{array}$ & 15 & $24.2 \%$ & 4 & $6.5 \%$ & 43 & $69.4 \%$ & 0.000 \\
\hline
\end{tabular}

\section{Source: Extract from respondents}


The responses of the nine participants who remained neutral lack of adequate information and hence they are not aware of any role of the MoFEP in their operations. These outcomes did not vary from the participants' expression about the effectiveness of the BoG's supervision where a significant $76 \%$ of the respondents disagreed (see Table 2) with the effectiveness of the BoG in promoting the course of the MFIs through supervision.

Though the rigour of reporting and feedback provide the policymaker with valid information on the implementation of existing policies the approach may either promote or retard implementation. Reporting is to ensure that MFIs are operating within the operating guidelines; it is also to promote (Ojo, 2013) sound financial practices and the sustainability of MFIs in Ghana. While several factors, including management quality and experience (Addae-Korankye, 2012; Ojo, 2013), were indicated by literature, the social character of MFIs is also cardinal to reporting. The survey to ascertain the implementation environment, which includes regulatory outcomes (discussed in the literature), through reporting was analyzed. A whopping 68.3 percent (see Table 2) indicated that reporting requirements are not creating a sound, sustainable environment for MF operation. This displeasure of the MFIs could be associated with some other factors, notably lack of resources and management quality (Ojo, 2013) and other characteristics discussed in the literature.

Despite the rigour of reporting the prevailing findings discovered inadequate and poorly integrated feedback from the BoG. Feedback facilitates policy review. It is the outcome of implementing the existing policies and such outcome or reports need to be evaluated, in order to assess the effectiveness of implementation and the realization of the intended objectives of formulating the policies for MFIs. Rather sadly, the respondents denied any relationship between offsite monitoring and onsite activities. Earlier analysis indicated poor supervision from the BoG and the GAMC, implying the sector lacks adequate onsite information, if any, and resulting in gross lack of industry data. The study results as to whether onsite and offsite reporting feedbacks are integrated showed 68.3 percent (see Table 2) of the survey outcome indicating onsite supervision, rarely carried out, is not reflected in the annual reports from the BoG. Though 14.3 percent indicated some integration of such monitoring and supervision reports, this is insignificant as 11 respondents, representing 17.5 percent of the total survey findings who remain neutral, exceeds any assertion of integration of supervision outcomes.

The study analysis regarding implementation challenges showed high correlation between level of minimum capital and capital adequacy (see p-value) which factors linked again the reviews in the minimum capital and its impact on the entire operation of the MFIs. Reporting requirements (75.4 percent) and human resource quality and lack of capacity building (74.6 percent) further positively correlated (p-value at 0.000 ). The quality of reporting directly relates to quality of human resource the MFIs deal with. Many of the MFIs are so small to develop in-house capacity to provide the needed training to enhance staff performance hence lack of support structures in terms of education and communication infrastructure as indicated by the results on $\operatorname{MoFEP}$ (68.3 percent), BoG (73.8 percent) and GAMC (76.4 percent) are enough substantiation that the MFIs lack all it takes to implement the policies for MF promotion in Ghana.

\section{The Financial Monitoring Policy Ownership Framework}

This paper conceptualises a three pillar (3-Pillar) financial monitoring policy ownership (FMPO) framework, presented in Figure 1. This study's '3-Pillar FMPO' is designed on the premise that participation in decision-making integrates the views of all interest groups (Hill \& Hupe, 2015; May, 2013, pp. 1-14). This is because the individual institutions' input will devolve into robust decisions that the MFIs will adopt to improve their operational performance.

The proposed conceptual framework was developed from the secondary data, confirmed by the findings based on the responses obtained from the primary sources and on the propositions of Barrett and Fudge's 1981 Policy-Action model and Action-Centred model discussed in the literature. It is thus a democratic model framework (May, 2013, pp. 1-14; Hallsworth \& Rutter, 2011, p. 18), which receives input from the firm internal structures (configuration, Pillar 1), comprising the MFIs and 


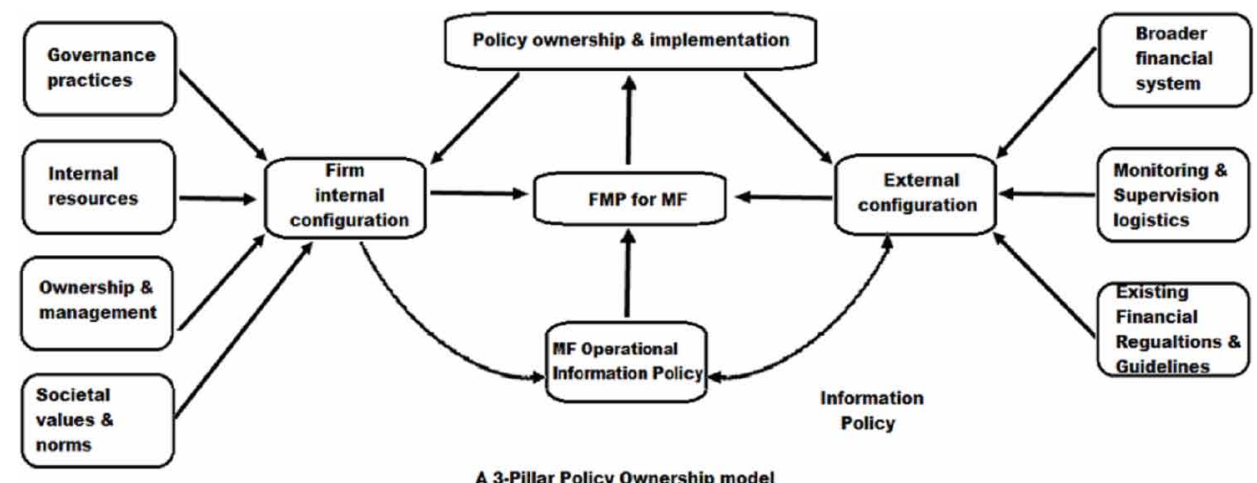

external configuration (Pillar 2) that represents the Bank of Ghana and therefore the financial rules. This study also assumes that this 3-pillar concept will devolve into a 'hybrid' institution (Pillar 3) and regulatory framework that will work better for MFIs than self-regulation practices since the MFIs will be able to internalise the existing guidelines.

Pillar 1 of this concept represented by firm internal configuration defines the MFI as the agency and agent in the policy-action model described above. Its major components of governance practices emphasized by 'ownership and management', internal resources and societal values and norms which determine the agency or the products the MFIs proffer. According to the Policy-Action model's structure and rules the External configurations representing Pillar 2 is fashioned. Currently, the financial institutions operate according to the laws governing the broader financial system legislative instruments and other specific operating guidelines and Acts of which the BoG has the mandate to ensure exact compliance. These two pillars are brought to one platform through negotiation and collaboration represented by Pillar 3: MF Operational Information Policy as per the Action-Centred model described above.

The effective negotiation, collaboration and cooperation from pillars 1 and 2 through pillar 3 will now devolve into FMP for MF which will lead to Policy Ownership \& Implementation. This is because each player in the policy formulation process has contributed and is satisfied with the content of the policy, adopted it as a collective document and understood its role in implementing it to the letter. That means policy dosage given and received is appropriate and matches the resources and capabilities of the MFIs therefore the processes of policy adoption and effective implementation will be faster.

This concept is relevant in addressing lapses and dominant role of the BoG in the policy making for MFIs and to allow for effective implementation because it involves interactive and collaborative efforts of all stakeholders, the MFIs, regulating institutions and the financial legal framework, in the formulation-implementation-reformulation cyclical process.

\section{CONCLUSION AND RECOMMENDATIONS}

The paper identified minimum capital requirement and its relative influence on capital adequacy, licensing and legal status and branching opportunities for MFIs as a mammoth challenge to the institutions. Lack of cooperation, both in the policy formulation process and during its implementation coupled with poor support structures, low quality human resource exacerbated by inadequate monitoring and supervision remain paramount in the policy implementation for MFIs in Ghana. Strategies to counter these elaborate problems are the surest way of promoting effective implementation of MF policies and ensuring adherence to the operating guidelines of the sector. In that regard, this 
paper elaborates recommendation of a National Microfinance Promotion Council to take over from the BoG in licensing, regulating and supervision of MFIs in Ghana. With this autonomous institution well resourced, the paper recognizes policies for MF dispensation will be well communicated, cooperation will be fostered and monitoring and supervision will step up to enhance implementation of the policies for the sector. The study therefore envisages prompt immediate review of the existing regulation through broad stakeholder consultation in all policy review processes especially by providing a leveled platform to major market participants to contribute to solving their market related challenges. This strengthens the MF Apex bodies and regularly engages them in sector specific policy reviews to increase stakeholder involvement for policy ownership and effective implementation. Finally, prompt consideration for establishment of recommended sector regulating council as being practiced by Bangladesh and South Africa (MFRC under the Usury Act) is expected. It is however noteworthy that the study was limited to Accra but can be nationalized as the MF exhibit the same characteristics. 


\section{REFERENCES}

Addae-Korankye, A. (2012). Microfinance and poverty reduction in Ghana. The Case of Central region of Ghana. Asian Economic and Financial Review, 2(1), 135-141.

Ali, A. E. E. S. (2015a). The regulatory and supervision framework of microfinance in Kenya. International Journal of Social Science Studies, 3(5), 123-130.

Ali, A. E. E. S. (2015b). The regulatory and supervisory framework of microfinance: Some evidence from Sudan. Asian Social Science, 11(15), 76-83. doi:10.5539/ass.v11n15p76

Bank of Ghana. (2011). Operating Rules and Guidelines for Microfinance Institutions Notice No BG/GOV/ SEC/2011/04/ (Accra: BoG).

Bank of Ghana. (2012). Notice to Banks, non-bank financial institutions and the general public (Accra: BoG).

Bank of Ghana. (2013a). Monetary Policy Report, Monetary and Financial Sector Development. Vol. 3 No.1.

Bank of Ghana. (2013b). Notice to Banks, non-bank financial institutions and the general public (Accra: BoG).

Bank of Ghana. (2015). Retrieved from www.bog.gov.gh

Boateng, A. A. (2015). An Examination of challenges and prospects of microfinance institutions in Ghana. Journal of Economics and Sustainable Development, 6(4), 52-61.

Cairney, P. (2012). Complexity theory in political science and public policy. Political Studies Review, 1-14.

CGAP. (2011). A guide to regulation and supervision of microfinance. Retrieved from www.cgap.org/sites/ default/files/Consensus

Dahir, A. M. (2015). The Challenges Facing Microfinance Institutions in Poverty Eradication: A Case Study in Mogadishu. International Journal of Humanities Social Sciences and Education, 2(2), 56-62.

Embrett, M. G., \& Randall, G. E. (2014). Social determinants of health and health equity policy research: Exploring the use, misuse, and nonuse of policy analysis theory. Social Science \& Medicine, 108, 147-155. doi:10.1016/j.socscimed.2014.03.004 PMID:24641879

Geyer, R. (2012). Can complexity move UK policy beyond 'evidence-based policy making' and the 'audit culture'? Applying a 'complexity cascade' to education and health policy. Political Studies, 60(1), 3-19. doi:10.1111/j.1467-9248.2011.00903.x

Gong, Y., \& Janssen, M. (2012). From policy implementation to business process management: Principles for creating flexibility and agility. Government Information Quarterly, 29, S61-S71. doi:10.1016/j.giq.2011.08.004

Hallsworth, M., \& Rutter, J. (2011). Making policy better. Institute for government, London.

Hill, M. J., \& Hupe, P. L. (2015). And the rest is implementation: Comparing approaches to what happens in policy processes beyond Great Expectations. In Public Policy and Administration. doi:1077/0952076715598828

Hoekstra, F., Alingh, R. A., van der Schans, C. P., Hettinga, F. J., Duijf, M., Dekker, R., \& van der Woude, L. H. V. (2014). Design of a process evaluation of the implementation of a physical activity and sports stimulation programme in Dutch rehabilitation setting: ReSpAct. Implementation Science; IS, 9(1), 127. doi:10.1186/ s13012-014-0127-7 PMID:25241188

Khalily, M. A. B., Khaleque, M. A., \& Badruddoza, S. (2014). Impact of regulation on the cost efficiency of microfinance institutions in Bangladesh. Institute of Microfinance.

Kinde, B. A. (2012). Financial sustainability of microfinance institutions (MFIs) in Ethiopia. European Journal of Business and Management, 4(15), 1-11.

Little, A. (2012). Political Action, Error and Failure: The Epistemological Limits of Complexity. Political Studies, 60(1), 3-19. doi:10.1111/j.1467-9248.2011.00901.x

Macchiavello, E. (2012). Microfinance regulation and supervision: A multi-faced prism of structures, levels and issues. NYU Journal of Law and Business, 9, 125. 
Magali, J. J. (2014). The influence of leadership, corporate governance and regulations on credit risk management: The study of rural SACCOS from Tanzania. Management and Administrative Sciences, 3(2), 262-281.

Mago, S. (2013). Microfinance in Zimbabwe: A historical overview. Mediterranean Journal of Social Sciences, 4(14), 599. doi:10.5901/mjss.2013.v4n14

Makuyana, T. (2016). Microfinance regulation and supervision in Zimbabwe: A critical overview. Mediterranean Journal of Social Sciences, 7(1), 376-385.

May, C. (2013). Towards a general theory of implementation. Implementation Science, 8(18), (p. 1-14).

May, P. J. (2014). Implementation failures revisited: Policy regime perspectives. Public Policy and Administration, $1-23$.

Mensah, C. (2013). The Relationship between loan default and repayment schedule in microfinance institutions in Ghana: A case study of Sinapi Aba Trust. Research Journal of Finance and Accounting, 4(19), 165-175.

Montgomery, A. W., Dacin, P. A., \& Dacin, M. T. (2012). Collective social entrepreneurship: Collaboratively shaping social good. Journal of Business Ethics, 111(3), 375-388. doi:10.1007/s10551-012-1501-5

Nilsen, P. (2015). Making sense of implementation theories, models and frameworks. Implementation Science; IS, 10(53), 1-13. doi:10.1186/s13012-015-0242-0

Nilsen, P., Ståhl, C., Roback, K., \& Cairney, P. (2013). Never the twain shall meet? - A comparison of implementation science and policy implementation research. Implementation Science, 8(63), 1-12.

Nzaro, R., Njanike, K., \& Jaravani, E. (2013). The impact of regulation policy on product and service delivery of micro-financial institutions: A case of Zimbabwe. In Global Advanced Research Journal of Management and Business Studies (pp. 429-438).

Ogbulu, O. M., Uruakpa, P. C., \& Umezinwa, C. L. (2015). Empirical investigation of the impact of deposit rates on fund mobilization by Deposit Money Banks in Nigeria. Journal of Finance and Bank Management, 3(1), 77-89. doi:10.15640/jfbm.v3n1a8

Ojo, M. (2013). Role of regulation in micro finance: Jurisdictional analysis (Africa, Asia and Latin America). In Conference Presentation: Global Development Finance Conference, Cape Town, South Africa (pp. 1-27). doi: $10.2139 /$ ssrn. 2349108

Pritchett, L., Woolcock, M., \& Andrews, M. (2012). Looking like a state: Techniques of persistent failure in state capability for implementation. WIDER.

Puyvelde, S. V., Caers, R., Du Bois, C., \& Jegers, M. (2012). The governance of nonprofit organizations: Integrating agency theory with stakeholder and stewardship theories. Nonprofit and Voluntary Sector Quarterly, 41(3), 429-451.

Quao, K. H., Lekhanya, L. M., \& Dorasamy, N. (2017). An investigation of the financial monitoring policies for microfinance institutions in Ghana. Investment Management and Financial Innovations, 14(4), 90-104. doi:10.21511/imfi.14(4).2017.09

Rahman, M. W., \& Luo, J. (2012). Regulation of microfinance service provider in China and Bangladesh: An approach to strengthening the regulatory environment. African Journal of Business Management, 6(3), 1019-1033.

Riquet, C., \& Poursat, C. (2013). Managing failing deposit-taking institutions: Regulatory experience from Africa. CGAP.

Rivera-Santos, M., Holt, D., Littlewood, D., \& Kolk, A. (2015). Social entrepreneurship in sub-Saharan Africa. $U v A-D A R E$, the institutional repository of the University of Amsterdam ( $U v A$ ).

Rycroft-Malone, J., Seers, K., Chandler, J., Hawkes, C. A., Crichton, N., Allen, C., \& Strunin, L. et al. (2013). The role of evidence, context, and facilitation in an implementation trial: Implications for the development of the PARIHS framework. Implementation Science; IS, 8(1), 28. doi:10.1186/1748-5908-8-28 PMID:23497438

Santos, F. (2012). A positive theory of social entrepreneurship. Journal of Business Ethics, 111(3), 335-351. doi:10.1007/s10551-012-1413-4 
Sarpong, L. S. (2016) Ghana's Microfinance's biggest challenges: Any Hope for the Future? Retrieved from www.modernghana.com

Segun, O., Hussein, A., Daniel, O., \& Olajide, A. (2015). Regulation of microfinance institutions in Africa major economies: A comparative analysis. International Journal of Business and Management, 3, 77-84.

Smith, K. E., \& Katikireddi, S. V. (2012). A glossary of theories for understanding policymaking. JECH. doi:10.1136/jech-2012-200990

Song, J., Wang, R., \& Cavusgil, S. T. (2015). State ownership and market orientation in China's public firms: An agency theory perspective. International Business Review, 24(4), 690-699. doi:10.1016/j.ibusrev.2014.12.003

Turner, N. W. (2012). The financial action task force: International regulatory convergence through soft law. 59. New York Law School Law Review. New York Law School, 547(2014-2015), 547-559.

Wampah, H. A. K. (2012). Monetary Policy Framework in Ghana: Practice and Challenges. Paper Presented at the International Conference on Monetary Policy Frameworks in Developing Countries: Practice and Challenges. The National Bank of Rwanda in collaboration with the IMF.

Wilkinson, J. E., \& Frost, H. (2015). "Horses for Courses". Comment on "Translating evidence into healthcare policy and practice: Single versus multi-faceted implementation strategies - Is there a simple answer to a complex question?" International Journal of Health Policy and Management, 4(10), 685-686. doi:10.15171/ ijhpm.2015.127 PMID:26673180 